\title{
Validation of assay indicating method development of meloxicam in bulk and some of its tablet dosage forms by RP-HPLC
}

\author{
Nalini Kanta Sahoo ${ }^{1 *}$, Madhusmita Sahu ${ }^{1}$, Podilapu Srinivasa Rao ${ }^{1}$, N Sandhya Rani ${ }^{1}$, JNV Indira Devi ${ }^{1}$
} and Goutam Ghosh ${ }^{2}$

\begin{abstract}
A novel, simple and economic reverse phase high performance liquid chromatography (RP-HPLC) method has been developed for the quantification of Meloxicam in bulk and tablet dosage form with greater precision and accuracy. Separation was achieved on Develosil ODS HG-5 RP $C_{18},(15 \mathrm{~cm} \times 4.6 \mathrm{~mm}$ i.d. $5 \mu \mathrm{m})$ column in isocratic mode with mobile phase consisting of acetonitrile: phosphate buffer( $\mathrm{pH}$ 3.4) (60:40) with a flow rate of $1 \mathrm{~mL} / \mathrm{min}$. The detection was carried out at $268 \mathrm{~nm}$. The retention time of Meloxicam was found to be $2.09 \mathrm{~min}$. The method was validated as per ICH guidelines. Linearity was established for Meloxicam in the range $20-120 \mathrm{\mu g} / \mathrm{ml}$ with $R^{2}$ value 0.996 . The percentage recovery of Meloxicam was found to be in the range 99.99-100.46\%. The high recovery and low relative standard deviation confirm the suitability of the proposed method for the estimation of the drug in bulk and tablet dosage forms. Validation studies demonstrated that the proposed RP-HPLC method is simple, specific, rapid, reliable and reproducible for the determination of Meloxicam for Quality Control level.
\end{abstract}

Keywords: RP-HPLC; Meloxicam; Quality control level

\section{Introduction}

Meloxicam (MEL), shown in Figure 1, is chemically, 4-hydroxy-2-methyl-N-(5-methyl-2-thiazolyl)-2H,1,2benzothaizine-3-carboxamide-1, 1-dioxide. It is used for the treatment of osteoarthritis, rheumatoid arthritis, and pauciarticular and polyarticular course juvenile rheumatoid arthritis. Its analgesic, antipyretic and antiinflammatory activity is due to the inhibition of COX-2 enzyme (Noble \& Balfour 1996; Davies \& Skjodt 1999). Meloxicam pharmacological activity is greatly affected by the substituents on parent oxicam moiety e.g. change in methyl to ethyl at 2 positions causes complete suppression of activity (Lemke \& Williams 2008). Several analytical methods for the determination of meloxicam by flourimetry (Hassan 2002), capillary electrophoresis (Nemutlu \& Kir 2003), spectrophotometry (Hassan 2002), HPLC (Arayne et al. 2005; Farzana \& Pradeep 2009;

\footnotetext{
* Correspondence: sahoo.nalini@gmail.com

${ }^{1}$ Yalamarty Pharmacy College, Tarluwada, Visakhapatnam 530052, AP, India Full list of author information is available at the end of the article
}

Damle et al. 2009), LC/MS (Wiesner et al. 2003) and polarographic (Altıokka et al. 2000; Radi et al. 2001a; Altınöz et al. 2002; Radi et al. 2001b; Rao et al. 2005) have been reported. The aim of the present work was to develop and validate a sensitive RP-HPLC method that can be implemented for the quantification of meloxicam in bulk as well as in its tablet dosage forms.

\section{Experimental Materials}

Pure Meloxicam (MEL) used as working standards, was purchased from Yarrow chem. Products, Mumbai, India. Tablets containing $15 \mathrm{mg}$ and $7.5 \mathrm{mg}$ of meloxicam (MUVERA15 and MOVAC) were obtained from Apollo Pharmaceuticals Pvt. Ltd, Visakhapatnam, India and used within their shelf life period. Acetonitrile and water (HPLC-grade) were purchased from Merck, India. All other chemicals and reagents employed were of analytical grade, and purchased from Merck, India. 


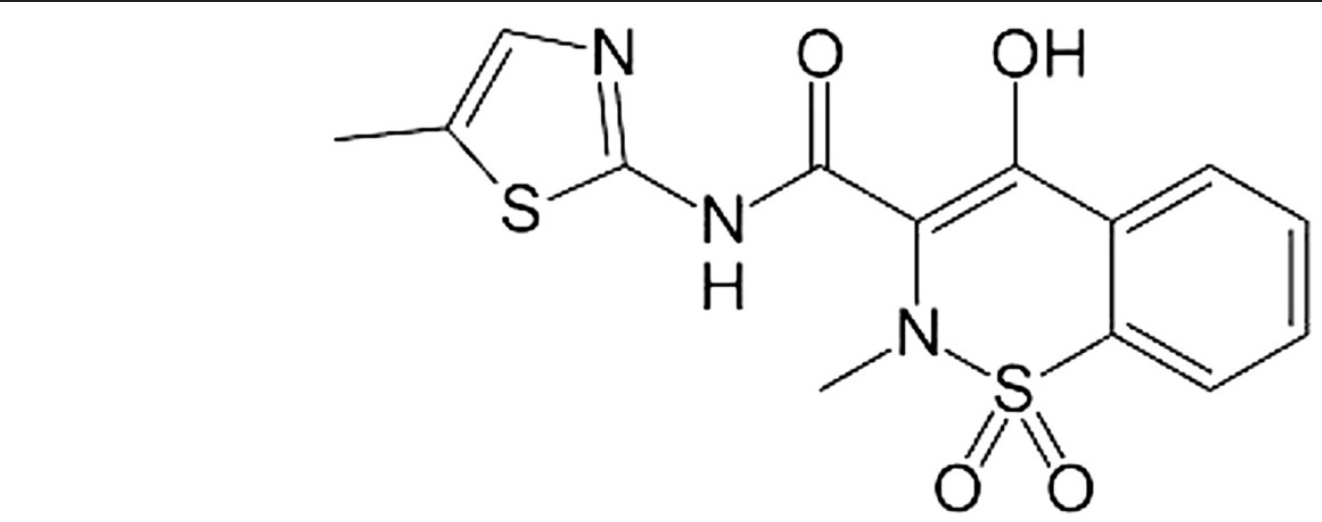

Figure 1 Chemical structure of Meloxicam.

\section{Instrumentation}

The chromatographic system used comprised of Analytical technologies ltd UV 2230 UV-vis detector. Data integration was carried out using A-4000 version software. Samples were injected into Develosil ODS HG$5 \mathrm{RP} \mathrm{C}_{18}(5 \mu \mathrm{m}, 15 \mathrm{~cm} \times 4.6 \mathrm{~mm}$ i.d $)$ column. An Analytical technologies ltd.sonicator was used for enhancing the dissolution of the compounds. A Wenster digital $\mathrm{pH}$ meter was used for $\mathrm{pH}$ adjustment.

\section{Chromatographic conditions}

The high performance liquid chromatographic (HPLC) system used was operated isocratically with the column temperature maintained at $30^{\circ} \mathrm{C}$, using a mobile phase composition of acetonitrile and phosphate buffer ( $\mathrm{pH}$ adjusted to 3.4 with O-Phosphoric acid) in the ratio of $60: 40 \mathrm{v} / \mathrm{v}$ at a flow rate of $1.0 \mathrm{~mL} / \mathrm{min}$ within a run time of $7 \mathrm{~min}$. Prior to use, the mobile phase was degassed by an ultrasonic bath and filtered by a Millipore vacuum filter system equipped with a $0.45 \mu \mathrm{m}$ high vacuum filter. The drug was detected and quantified at $268 \mathrm{~nm}$.

\section{Preparation of standard solutions}

The stock solution was prepared by transferring $100 \mathrm{mg}$ of Meloxicam into $100 \mathrm{~mL}$ volumetric flask. Then it was added with small amount of diluent [acetonitrile: water (50:50)], and the mixture was sonicated to dissolve and made up to volume with mobile phase. From this stock solution different concentrations were prepared to give final concentrations of $20-120 \mu \mathrm{g} / \mathrm{mL}$ for standard calibration curve.

\section{Assay of meloxicam from marketed tablets}

Twenty tablets were accurately weighed and crushed to a fine powder in a mortar in each of the marketed formulation separately. An amount of the powder equivalent to $100 \mathrm{mg}$ was transferred into a $100 \mathrm{~mL}$ volumetric flask and $10 \mathrm{~mL}$ of diluent was added to it followed by $10 \mathrm{ml}$ of $0.1 \mathrm{~N} \mathrm{NaOH}$. The mixture was sonicated to dissolve the exipients and then made up to volume with mobile phase. Following 15 min of mechanical shaking, it was kept in an ultrasonic bath for 15 mins, and the solution was filtered through a $0.45 \mu \mathrm{m}$ filter paper. Suitable aliquots $(1 \mathrm{ml}$ each) of the filtered solution were

Table 1 Results of optimization

\begin{tabular}{|c|c|c|c|c|c|}
\hline Column used & Mobile phase & Flow rate & Wave length & Observation & Result \\
\hline $\begin{array}{l}\text { Microbondapak } \mathrm{C}_{18}, 5 \mu \mathrm{m} \text {, } \\
50 \times 4.6 \mathrm{~mm} \text { i.d. }\end{array}$ & Methanol only & $0.5 \mathrm{ml} / \mathrm{min}$ & $254 \mathrm{~nm}$ & Low resolution below 1 . & Method rejected \\
\hline $\begin{array}{l}\text { Phenomenex RP- } C_{18} \text {, Luna } 5 \mu \mathrm{m} \text {, } \\
250 \times 4.6 \mathrm{~mm} \text { i.d. }\end{array}$ & Acetonitrile only & $0.8 \mathrm{ml} / \mathrm{min}$ & $358 \mathrm{~nm}$ & $\begin{array}{l}\text { Resolution i.e. } 1.2 \text { but } \\
\text { not satisfied }\end{array}$ & Method rejected \\
\hline $\begin{array}{l}\text { Microbondapak } C_{18}, 5 \mu \mathrm{m} \text {, } \\
50 \times 4.6 \mathrm{~mm} \text { i.d. }\end{array}$ & $\begin{array}{l}\text { Acetonitrile: phosphate } \\
\text { buffer }(\mathrm{pH} 7.8)=70: 30\end{array}$ & $1 \mathrm{ml} / \mathrm{min}$ & $270 \mathrm{~nm}$ & Poor resolution i.e. 1.5 & Method rejected \\
\hline $\begin{array}{l}\text { Phenomenex RP- } C_{18} \text {, Luna } 5 \mu \mathrm{m} \text {, } \\
250 \times 4.6 \mathrm{~mm} \text { i.d. }\end{array}$ & $\begin{array}{l}\text { Acetronitrile: phosphate } \\
\text { buffer }(\mathrm{pH} 5.0=60: 40\end{array}$ & $1 \mathrm{ml} / \mathrm{min}$ & $270 \mathrm{~nm}$ & Poor resolution i.e. 1.2 & Method rejected \\
\hline $\begin{array}{l}\text { Develosil ODS HG-5 RP } \mathrm{C}_{18}, 5 \mu \mathrm{m} \text {, } \\
15 \mathrm{~cm} \times 4.6 \mathrm{~mm} \text { i.d. }\end{array}$ & $\begin{array}{l}\text { Acetonitrile: phosphate } \\
\text { buffer(pH 3.4) (60:40) }\end{array}$ & $1 \mathrm{ml} / \mathrm{min}$ & $268 \mathrm{~nm}$ & $\begin{array}{l}\text { Sharp peak and good } \\
\text { resolution i.e. } 2.3\end{array}$ & Method accepted \\
\hline
\end{tabular}




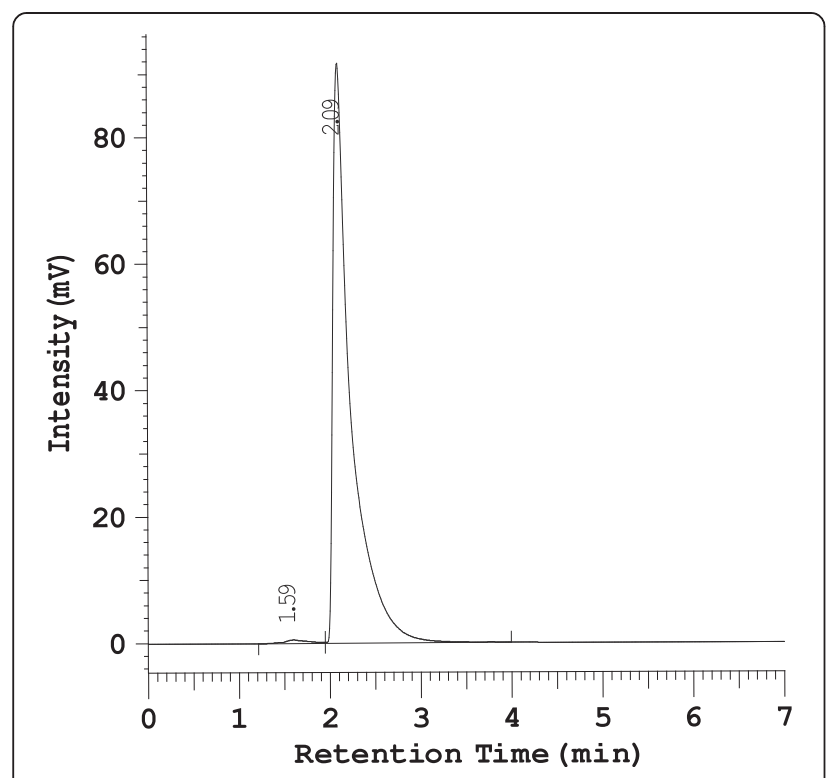

Figure 2 RP-HPLC Chromatogram of Meloxicam standard drug.

transferred to $50 \mathrm{ml}$ volumetric flasks and made up to volume with mobile phase to yield six concentrations of Meloxicam $(20 \mu \mathrm{g} / \mathrm{mL})$. A $20 \mu \mathrm{L}$ volume of the sample solution was injected into the chromatographic system, six times, under optimized chromatographic conditions. The peak areas were measured at $268 \mathrm{~nm}$ and concentrations in the samples were determined by interpolation from standard calibration curve of each drug previously obtained.

\section{Method validation}

The method was validated in accordance with ICH guidelines (International Conference on Harmonization (ICH) of Technical Requirements for Registration of Pharmaceuticals for Human Use 2010). The parameters assessed were
Table 2 Results of linearity and range

\begin{tabular}{ccc}
\hline Sl. no & Conc. & Area \\
\hline 1 & 20 & 1000024 \\
2 & 40 & 1698687 \\
3 & 60 & 2502000 \\
4 & 80 & 3213014 \\
5 & 100 & 3824253 \\
6 & 120 & 4605216 \\
\hline
\end{tabular}

linearity, accuracy, and limit of detection (LOD), limit of quantification (LOQ), precision, reproducibility, robustness and system suitability.

\section{Accuracy}

Accuracy was best determined by the standard addition method. Previously analyzed samples of Meloxicam API were added with standard drug solutions and are analyzed by the proposed method. Recovery (\%), RSD (\%) and bias (\%) were calculated for each concentration.

Accuracy is reported as percentage bias, which is calculated from the expression

$$
\% \text { Bias }=\frac{(\text { measured value }- \text { true value })}{\text { true value }} \times 100
$$

\section{Precision}

Precision was determined as both repeatability and intermediate precision, in accordance with $\mathrm{ICH}$ guidelines. Repeatability of sample injection was determined as intraday variation and intermediate variation. For these determinations, single concentration $(20 \mu \mathrm{g} / \mathrm{ml})$ at different time intervals and different days, of the solution of Meloxicam API was used.

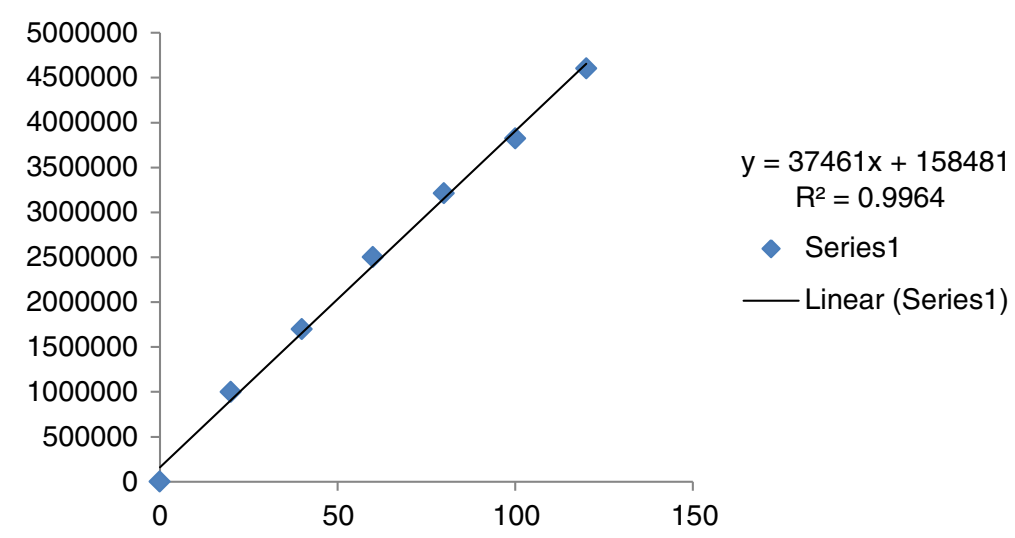

Figure 3 Calibration curve for Meloxicam. 
Table 3 Results of recovery study

\begin{tabular}{|c|c|c|c|c|}
\hline \multirow{2}{*}{$\begin{array}{l}\text { Amount of drug } \\
\text { added }(\mu \mathrm{g}) \\
\text { to analyte }\end{array}$} & \multicolumn{4}{|c|}{ Recovery from formulation } \\
\hline & $\begin{array}{l}\text { Mean amount ( } \mu \mathrm{g}) \\
\text { found }(n=6)\end{array}$ & $\begin{array}{l}\text { Mean \% } \\
\text { recovery }\end{array}$ & \% RSD & $\%$ Bias \\
\hline 32 & 32.148 & 100.46 & 1.662 & 0.462 \\
\hline 40 & 40.021 & 100.05 & 1.502 & 0.052 \\
\hline 48 & 47.954 & 99.99 & 0.2757 & -0.095 \\
\hline
\end{tabular}

\section{Robustness}

The concept of robustness of an analytical procedure has been defined by the $\mathrm{ICH}$ as "a measure of its capacity to remain unaffected by small but deliberate variations in method parameters". To determine the robustness of the method experimental conditions are purposely altered and chromatographic characters are evaluated. Influence of small changes in chromatographic conditions such as change in flow rate $( \pm 0.1 \mathrm{ml} / \mathrm{min})$, wavelength of detection $( \pm 2 \mathrm{~nm})$ and acetonitrile content in mobile phase $( \pm 2 \%)$ were studied to determine the robustness of the method.

\section{Limit of detection (LOD)}

The limit of detection (LOD) of an analytical method may be defined as the concentration, which gives rise to an instrument signal that is significantly different from the blank. For spectroscopic techniques or other methods that rely upon a calibration curve for quantitative measurements, the IUPAC approach employs the standard deviation of the intercept $(\mathrm{Sa})$, which may be related to LOD and the slope of the calibration curve, b, by

$$
\mathrm{LOD}=3 \mathrm{Sa} / \mathrm{b}
$$

\section{Limit of quantitation (LOQ)}

The LOQ is the concentration that can be quantitated reliably with a specified level of accuracy and precision. The LOQ represent the concentration of analyte that would yield a signal-to-noise ratio of 10 .
Table 5 Results of robustness test

\begin{tabular}{lc}
\hline Change in parameter & \% RSD $(\mathbf{n}=\mathbf{6})$ \\
\hline Flow $(0.9 \mathrm{ml} / \mathrm{min})$ & 0.14 \\
Flow $(1.1 \mathrm{ml} / \mathrm{min})$ & 0.02 \\
Wavelength of Detection $(270 \mathrm{~nm})$ & 0.09 \\
Wavelength of detection $(266 \mathrm{~nm})$ & 0.61 \\
Acetonitrile: Phosphate buffer $(62: 38)$ & 0.14 \\
Acetonitrile: Phosphate buffer $(58: 42)$ & 0.19 \\
\hline
\end{tabular}

$$
\mathrm{LOQ}=10 \mathrm{Sa} / \mathrm{b}
$$

Where, Sa is the standard deviation of the peak area ratio of analyte to IS (6 injections) of the drugs and b is slope of the corresponding calibration curve.

\section{Results and discussion}

\section{Optimization of chromatographic conditions}

The chromatographic conditions were optimized by different means i.e. using different column, different mobile phase, different flow rate, different detection wavelength and different diluents for standard drug and marketed tablets are summarized in Table 1 and different chromatograms (Figure 2) are shown.

\section{Linearity \& range}

The standard calibration curve(Figure 3) showed good linearity in the range of $20-120 \mu \mathrm{g} / \mathrm{ml}$ (Table 2), for Meloxicam API with correlation coefficient $\left(r^{2}\right)$ of 0.996 . A typical calibration curve has the regression equation of $y=37461 x+158481$ for Meloxicam.

\section{Accuracy: recovery study}

The recovery of the method, determined by adding a previously analyzed test solution with additional drug standard solution at three levels of concentration, was $99.99-100.46 \%$. The values of recovery (\%), RSD (\%) and $\%$ Bias listed in Table 3 indicate the method is accurate.

\section{Precision: Intra-assay \& inter-assay}

The intra \& inter day variation of the method was carried out and the high values of mean assay and low

\begin{tabular}{|c|c|c|c|c|c|}
\hline \multirow{3}{*}{$\begin{array}{l}\text { Conc. of Meloxicam } \\
\qquad(20 \mu \mathrm{g} / \mathrm{ml})\end{array}$} & \multicolumn{5}{|c|}{ Observed conc. of Meloxicam $(\mu \mathrm{g} / \mathrm{ml})$ by the proposed method } \\
\hline & \multicolumn{2}{|c|}{ Intra-Day } & & \multicolumn{2}{|c|}{ Inter-Day } \\
\hline & Mean $(n=6)$ & $\%$ RSD & & Mean $(n=6)$ & $\%$ RSD \\
\hline 9 A.M & 22.463 & 0.01 & Day 1 & 21.89 & 0.08 \\
\hline 1 P.M & 22.463 & 0.01 & Day 2 & 21.93 & 0.04 \\
\hline 5 P.M & 22.463 & 0.01 & Day 3 & 20.99 & 0.01 \\
\hline
\end{tabular}

Table 4 Results of intra-assay \& inter-assay 
Table 6 Assay of meloxicam tablets

\begin{tabular}{ccccccc}
\hline S. No & Formulations & Standard peak area & Sample peak area & Labeled amount $(\mathbf{m g})$ & Amount found (mg) & \% Assay \pm RSD \\
\hline 1 & Muvera 15 & 1000024 & 1000011 & 15 & 14.99 & $99.99 \pm 0.12$ \\
2 & Movac & 1000024 & 1000191 & 7.5 & 7.5 & $100.01 \pm 0.02$ \\
\hline
\end{tabular}

values of standard deviation and \% RSD (\% RSD < 2\%) within a day and day to day variations for Meloxicam revealed that the proposed method is precise (Table 4).

\section{Robustness}

Influence of small changes in chromatographic conditions such as change in flow rate $( \pm 0.1 \mathrm{ml} / \mathrm{min})$, Wavelength of detection $( \pm 2 \mathrm{~nm})$ \& acetonitrile content in mobile phase $( \pm 2 \%)$ studied to determine the robustness of the method are also in favor of (Table 5, \% RSD $<2 \%$ ) the developed RP-HPLC method for the analysis of Meloxicam API.

\section{LOD \& LOQ}

The Minimum concentration level at which the analyte can be reliable detected (LOD) \& quantified (LOQ) were found to be $0.42 \& 1.29 \mu \mathrm{g} / \mathrm{ml}$ respectively.

\section{Assay of meloxicam in tablet dosage forms}

Assay was performed by using the regression equation $\left(y=37461 x+158481, R^{2}=0.996\right)$ obtained from the standard calibration curve of Meloxicam API. Results obtained are given in Table 6. The assay of Muvera 15 and Movac tablet containing Meloxicam was found to be 99.99 and $100.01 \%$ respectively as per the method. The chromatograms are represented in Figures 4 and 5.

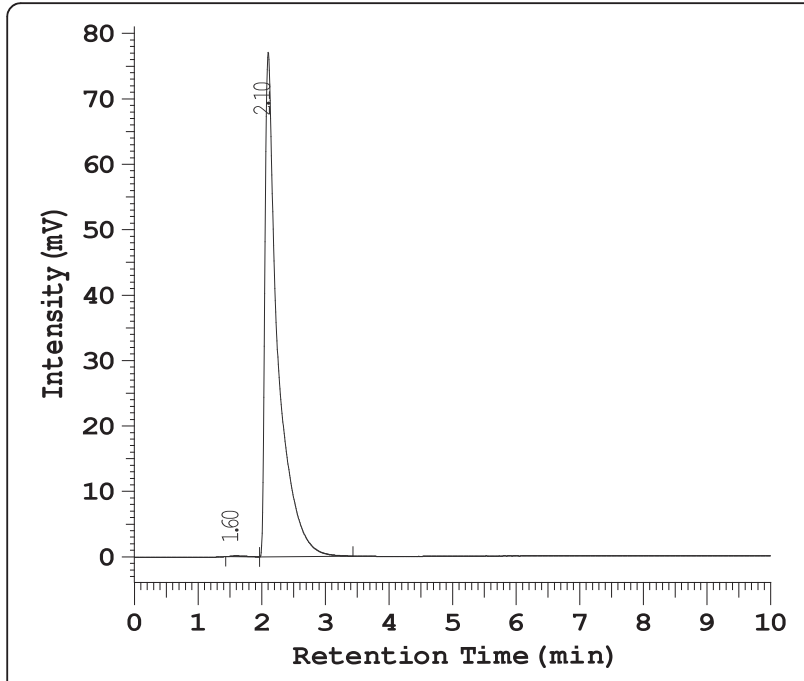

Figure 4 RP-HPLC Chromatogram of Muvera 15 Tablet.
The method is having linearity in the range 20 to $120 \mu \mathrm{g} / \mathrm{ml}$ with regression coefficient value 0.99 . When compared to previous methods for recovery study, the \% recovery is nearly $100 \%$. Precision results are having low \% RSD value i.e. below 0.1 in comparison to previous methods, which is an added advantage. Similarly in previous methods assay in marketed formulation is carried out by considering single formulation, but the present method uses two different formulations. Also at very low concentration it can be detected and quantified i.e. at $0.42 \& 1.29 \mu \mathrm{g} / \mathrm{ml}$, which is not observed in previous methods. For these reasons the method is proved to be novel in comparision to existed methods.

\section{Conclusion}

A New RP-HPLC method indicating assay of MEL in bulk and in pharmaceutical dosage forms is established. This method is simple, reliable, linear, accurate, sensitive and reproducible as well as cost effective for the effective quantitative analysis of MEL in bulk and tablet formulations. The method was completely validated showing satisfactory data for all the method validation parameters tested and method is free from interference of the other active ingredients and additives used in the formulations. Therefore the method is suitable for use of the routine quality control analysis of Meloxicam in API or in pharmaceutical dosage forms.

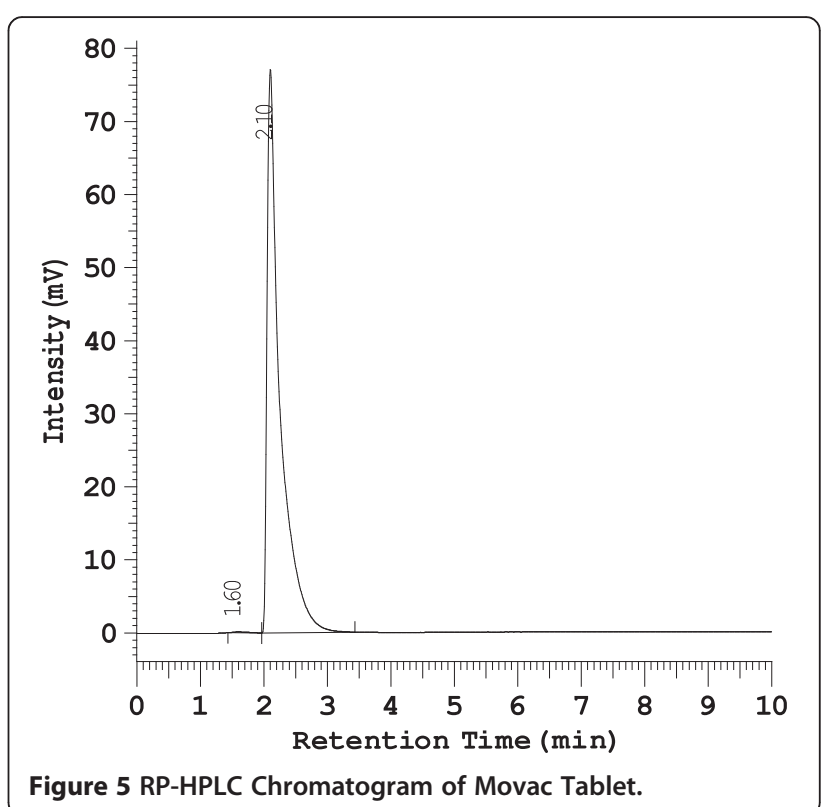




\section{Competing interests}

The authors declare that they have no competing interests.

\section{Authors' contributions}

NK has designed the entire procedure and done the entire work. M has done method optimisation. PS and $\mathrm{G}$ has done some validation parameters. $\mathrm{JN}$ and $\mathrm{N}$ have done rest of validations. All the authors have read the article and approved the final manuscript.

\section{Acknowledgements}

The authors would like to acknowledge the contributions of Yalamarty Pharmacy College, Tarluwada, Anandapuram, Visakhapatnam, Andhra Pradesh, India for providing necessary facilities to carny out the research work.

\section{Author details}

YYalamarty Pharmacy College, Tarluwada, Visakhapatnam 530052, AP, India. ${ }^{2}$ School of Pharmaceutical Sciences, SOA University, Kalinganagar, 751003

Orissa, BBSR, India.

Received: 12 November 2013 Accepted: 10 February 2014

Published: 18 February 2014

\section{References}

Altınöz S, Nemutlu E, Kır S (2002) Polarographic behaviour of meloxicam and its determination in tablet preparations and spiked plasma. Farmaco 57:463-468

Altıokka G, Atkosar Z, Tuncel M (2000) Pulse polarographic determination of meloxicam. Pharmazie 56:184-185

Arayne MS, Sultana N, Siddiqui FA (2005) A new RP-HPLC method for analysis of meloxicam in tablets. Pak J Pharm Sci 18:58-62

Damle MC, Sinha PK, Jeswani RM, Topagi KS (2009) A validated RP-HPLC method for determination of Meloxicam in the Presence of its Impurities. Int J Pharm Tech Res 1:1051-1060

Davies NM, Skjodt NM (1999) Clinical pharmacokinetics of meloxicam. Clin Pharmacokinet 36:115-122

Farzana SB, Pradeep RV (2009) A stability indicating HPLC method for the determination of meloxicam in bulk and commercial formulations. Trop $\mathrm{J}$ Pharm Res 8:257-264

Hassan EM (2002) Spectrophotometric and fluorimetric methods for the determination of meloxicam in dosage forms. J Pharm Biomed Anal 27:771-793

International Conference on Harmonization (ICH) of Technical Requirements for Registration of Pharmaceuticals for Human Use (2010) Harmonized Triplicate Guideline on Validation of Analytical Procedures: Methodology,

Recommended for Adoption at Step 4 of the ICH Process on November 1996 by the ICH Steering Committee. IFPMA, Switzerland

Lemke LT, Williams AD (2008) Foye's Principles of Medicinal Chemistry. W. Lippincot and wilkin, New York

Nemutlu E, Kir S (2003) Method development and validation for the analysis of meloxicam in tablets by CZE. J Pharm Biomed Anal 31:393-405

Noble S, Balfour JA (1996) Meloxicam. Drugs 51:424-431

Radi A, El-Ries MA, El-Anwar F, El-Sherif Z (2001a) Electrochemical oxidation of meloxicam and its determination in tablet dosage form. Anal Lett 34:739-748

Radi AE, Ghoneim M, Beltagi A (2001b) Cathodic adsorptive stripping square-wave voltammetry of the anti-inflammatory drug meloxicam. Chem Pharm Bull 49:1257-1260

Rao RN, Meena S, Rao AR (2005) An overview of the recent developments in analytical methodologies for determination of COX-2 inhibitors in bulk drugs, pharmaceuticals and biological matrices. J Pharm Biomed Anal 39:349-367

Wiesner JL, De Jager AD, Sutherland FCW, Hundt HKL, Swart KJ, Hundt AF, Els J (2003) Sensitive and rapid liquid chromatography-tandem mass spectrometry method for the determination of meloxicam in human plasma. J Chromatogr B 785:115-121

doi:10.1186/2193-1801-3-95

Cite this article as: Sahoo et al:: Validation of assay indicating method development of meloxicam in bulk and some of its tablet dosage forms by RP-HPLC. SpringerPlus 2014 3:95.

\section{Submit your manuscript to a SpringerOpen ${ }^{\circ}$ journal and benefit from:}

- Convenient online submission

Rigorous peer review

- Immediate publication on acceptance

- Open access: articles freely available online

- High visibility within the field

- Retaining the copyright to your article

Submit your next manuscript at $>$ springeropen.com 